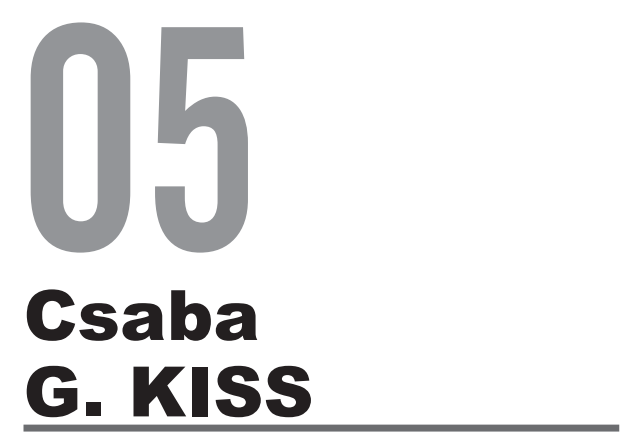

\title{
Budimpešta
}

Pregledni znanstveni rad

\section{Ferenc Fejtö i Mađarska između 1988. i 1990. Nedovršeni zapisi}

$\checkmark$

elio bih započeti jednim osobnim trenutkom. Zajedno s Jenőom Andicsem, voditeljem sjedišta stranke i Györgyem Dalosom koji je tada živio u Zapadnoj Njemačkoj bio sam pozvan da uvečer 26. svibnja 1988. sudjelujem u talk showu bečke televizije Club 2 koji je vodio Paul Lendvai. Nekoliko dana nakon što je János Kádár skinut s vlasti. Ime Ferenca Fejtöa nije mi bilo nepoznato. Dobro se sjećam kako sam 1976. kao stipendist u Varšavi mogao čitati njegove knjige na francuskom. O mađarskoj revoluciji i povijesti narodnih demokracija. Ovi su se radovi bez problema mogli posuditi iz varšavskog Instituta za međunarodne studije. Sentimentalno putovanje sam pak pronašao još početkom 80-ih u jednom antikvarijatu tu u Mađarskoj. U tu knjigu sam ga tražio posvetu prije te emisije u Beču. Napisao mi je sljedeće riječi: „Csabi Györgyu Kissu, uz naklonost prema njemu i njegovom pokretu. Beč, svibanj 1988." Da ne bi došlo do zabune, taj pokret bio je Magyar Demokrata Fórum (Mađarski demokratski forum). Iduće jutro za doručkom u hotelu pitao me što radim prijepodne u Beču. Morao sam kupiti nekoliko stvari na što je on odgovorio da bi mi pravio društvo. Tako me, dok smo šetali ulicom Kärtnerstrasse, ispitivao o "mom pokretu“. Kao netko tko je zainteresiran za sve. Tad je već iza nas bio forum održan u Kazalištu Jurta koji smo 15. svibnja organizirali u suradnji s klubom Nyilvánosság Klub (Klub Javnost), gdje su na dnevnom redu bili javni mediji. Tih smo dana bili u najvećem poslu oko orga- 
nizacije tih događaja, sigurno sam mu pričao o našem „izvještaju“ o položaju rumunjskih Mađara koji je bio namijenjen međunarodnoj javnosti. Stalno je postavljao pitanja, nisam uspio stvoriti sliku o tome kako on vidi naše izglede.

16. lipnja primili smo vijest o simboličnom pokopu Imrea Nagya i njegovih suradnika na pariškom groblju Père Lachaise. Glavni organizator svečane ceremonije bio je Ferenc Fejtö, tada u službi predsjednika Mađarske lige za ljudska prava u Francuskoj. Tek sam kasnije saznao da je tog ljeta dovršio svoje veliko srednjoeuropsko djelo, povijesni esej pod nazivom Rekviem egy hajdanvolt birodalomért (Rekvijem za carstvo iz davnina).

Kako se ja ne bavim istraživanjem njegovog opusa, u ovom bih predavanju, kronološki ih poredavši, htio spomenuti samo nekoliko slika koje dočaravaju kako je Ferenc Fejtö reagirao na promjene u Mađarskoj u tim sudbonosnim godinama. Dodao bih i, kao što sam već mnogo puta rekao, no uvijek se čini aktualnim, kako je nazvati razdoblje „promjenom sustava” poseban hungaricum. U drugim se jezicima govori o padu komunizma, kraju sovjetskog totalitarizma, prekretnici, prijelazu. Mađarski termin ostavlja zamagljenim kako je između sustava i sustava postojala kvalitativna razlika, da i ne govorimo kako je u našem slučaju promjena značila i odlazak sovjetskih trupa koje su izvršile invaziju. Time je završio jedan poseban eksperiment modernizacije na koji nas je prisilila vlast koja je civilizacijski zaostajala za nama. Naravno, kod nas je termin promjena sustava služio za prikrivanje postkomunističkih ambicija.

Nameće mi se pitanje što je Ferenc Fejtö mislio o vlastitoj mogućoj ulozi u procesu tranzicije. Znamo da ga je francuski politički i intelektualni život smatrao jednim od najvrsnijih srednjoeuropskih stručnjaka. Imajući u vidu tek obrise njegova životnog puta i mentaliteta, smatram da je imao osjećaj kao da je to njegova misija. Bilo bi teško odrediti kakva je, ako je i postojala, njegova uloga u transformaciji Mađarske. Teško je izmjeriti koliki je bio njegov stvarni utjecaj, budući da su se događaji ubrzavali; a dominantne silnice međunarodne politike i dinamični pokreti unutar države iznenadili su i promatrače i sudionike.

Za pitanje transformacije zasigurno je značajan doprinos, iako nije nastao s tom namjerom, veliki intervju koji je priredila Ágnes Széchenyi u prosinačkom izdanju časopisa Kritika iz 1988. Znamo da je intervju snimljen godinu dana ranije. Ovaj tekst je prvenstveno prisjećanje, ali podsjećanjem na narodno-urbanu raspravu imao je nenamjernu intelektualno-političku poruku, jer su strani analitičari također koristili tu razliku za razdvajanje dvaju glavnih pokreta oporbenih skupina koje su tada bile u procesu formiranja. 30. siječnja 1988. u Kazalištu Jurta u raspravi o parlamentarizmu jedan za drugim progovorili su Zoltán Bíró i János Kis, te György Konrád, István Csurka i György Szabad, a izvjesna linija razdvajanja ocrtavala se već od 1. svibnja, kada je kao organizacija nastala Szabad Kezdeményezések Hálózata (Mreža slobodnih inicijativa). Mađarski demokratski forum u tom je vremenu podrazumijevao samo skupinu organizatora od devet ljudi. Naime, intervju s Ferencom Fejtöm 
u određenoj je mjeri aktualizirao sukob koji je komunistička vlast dugo vremena bila sklona koristiti kao manipulaciju. Vrijedi promotriti jezik tajnih službi, u njihovim se izvješćima lako može pratiti dvoslojna shema: građanska radikalna oporba nasuprot nacionalističkoj oporbi i slično. Ferenc Fejtö kao da 1998. nastavlja rasprave iz tridesetih godina: „Moram primijetiti - piše - da je "pokret narodnih pisaca - kao specifični mađarski fenomen - u srodstvu s takozvanim narodnicima i populistima, s izvjesnim francuskim pravcem »natrag k zemlji k koji se povezuje s imenom radikalnog nacionalista Barrèsa." O časopisu pokreta narodnih pisaca Válasz otvoreno tvrdi da uredništvo časopisa nije zanimala demokracija. On, Fejtö smatra da je i Gyula Illyés na neki način u svom radu demokraciju stavio u zagrade. Fejtö je osobito oštro osuđivao Lászla Németha: „Moram priznati da Lászla Németha smatram možda najštetnijim elementom u ovoj cijeloj garnituri. Možda baš zato što ga se s druge strane može cijeniti kao talentiranog romanopisca i esejista iznimno velike obrazovanosti i univerzalne upućenosti. Ali kako da kažem, te njegove teorije vezane upravo uz svojstva naroda, duboko mađarstvo i kulturni antisemitizam, prouzročile su stoljetnu pomutnju kod mađarskih intelektualaca. [...] László Németh preuzeo je takvu doktrinu, koja - iz svega što sam čuo ovo zaključujem - očito i danas živi, štoviše možda je kod inteligencije, u krugu srednjeg staleža, dominantna, ali koja je zapravo duže vrijeme sprječavala, a vjerojatno će i dalje sprječavati, uzdizanje mađarstva na europski nivo. ${ }^{2}$ Vjerujem da bi teško bilo osporiti da se te riječi mogu smatrati porukom poslanom tadašnjim suvremenicima. Naravno, nije svejedno ni koje glasilo ju je odaslalo. Glasilo odano vlasti koje si je tada već moglo dopustiti reformkomunističke izgrede.

Slični su tonovi onih primjedaba - također iz druge polovice 80-ih godina koje je 1990. godine unio u svoje memoare objavljene na mađarskom jeziku pod naslovom Budapesttől Párizsig: Emlékeim (Od Budimpešte do Pariza preko Zagreba). I ovdje dosljedno rabi izraz narodni koji se rimuje s nacističkim völkisch. „Narodni pokret je najsnažniji tamo gdje modernizam ulazi u jedno posebno hijerarhijsko društvo usko povezano s tradicijom. To je bio slučaj u Mađarskoj. U ovom slučaju narodni pokret je reakcija; buntovnička reakcija na kapitalistički proces industrijalizacije koji su Marx i Engels tako sjajno analizirali u Komunističkom manifestu 1847-48. godine”. ${ }^{3}$ Ili u sljedećem: „Činjenica je da pokret i danas izražava otpor prema komunističkom poretku. Može li se taj utjecaj pripisati njihovoj nacionalističkoj retorici u kojoj uvijek postoje antisemitski prizvuci? Ili možda tome da prividno imaju rješenje za dilemu ma-

1 Széchenyi Ágnes, „Kérdések a Válaszról (Fejtő Ferenccel beszélget Széchenyi Ágnes)”, Kritika 26, 12.sz. (1988): 11-16.

2 Széchenyi Ágnes, „Kérdések a Válaszról”, Kritika 26, 12.sz. (1988): 11-16.

3 Vidi: Fejtő Ferenc. Budapesttől Párizsig: Emlékeim, (Budapest: Magvető Kiadó,1990), 124. 
đarskog naroda koji je stiješnjen između Istoka i Zapada." ${ }^{4}$ Fejtö dosljedno koristi izraz "narodni" koji je sam po sebi imao blago stigmatizirajuću primjesu. Pozivanje na Komunistički manifest tada je, blago rečeno, zvučalo groteskno.

Početkom 1989. godine u Kritici se pojavila polemika u vezi s intervjuom u kojem je glavni urednik Szerdahelyi (važan član komunističkog književnog establishmenta) dodao nekoliko kritičkih primjedbi uz Fejtövo osvrtanje na prošlost. Kritizirani je to spremno uspio odbaciti uzimajući u obzir tada već oslabljen utjecaj cenzure: „Zadržavam pravo na mišljenje da je László Németh, pored Györgya Lukácsa, najštetnije utjecao na mađarski duh. [...] Na primjer, što se tiče Lászla Németha, tvrdim da sa svojim djelima Kisebbségben (U manjini) i A minőség forradalma (Revolucija kvalitete), da spomenem samo ova dva, i u današnjem antisemitizmu nesumnjivo ima odlučujuću ulogu..." ${ }^{5}$

Ne može se znati kada je točno Fejtö uvidio da je povijest komunistički sustav osudila na pad. U knjizi intervjua koju je priredila Anita Földes prisjeća se kako je početkom 1989. sudjelovao na jednoj konferenciji povjesničara u Italiji na kojoj su, karakteristično za zapadnjački pogled, raspravljali o tome može li se komunizam reformirati. Naš se junak ovako sjeća: „... i dalje sam bio gotovo jedini u cijelom međunarodnom društvu koji je zastupao mišljenje da bi isključivo uz pomoć decentralizacije i uvođenja demokratskih institucija postojala ikakva mogućnost za to." Ako se dobro sjećam, 1988. i prvom polovicom 1989. godine većina je zapadnih političara, diplomata i novinara „izvršitelje" promjene, one koji će osigurati njezin mirni tijek vidjela u takozvanim reformkomunistima.

Ferenc Fejtö se prvi put vratio u Mađarsku nakon dobrih pola stoljeća izbivanja, 13. lipnja 1989. Kasnije se toga ovako prisjeća: „Bio sam u dobrim odnosima s kćeri Imrea Nagya, rado sam se odazvao njezinom pozivu. Na dan mog povratka po mene su u zračnu luku došli Emil Grandpierre Kolozsvári i povjesničarka književnosti Ágnes Széchenyi, zatim sam ručao s Árpádom Gönczem. Njega sam upoznao 1988. kada je kao predsjednik Saveza književnika bio u Parizu zajedno sa Sándorom Csoórijem, jednim od duhovnih i političkih vođa pokreta narodnih pisaca. Tada su se još u svemu slagali. Csoóri je bio veliki demokrat, a Göncz je to i ostao..." Organizatorica programa Ágnes Széchenyi prisjeća se tih šest dana 2008. u časopisu Élet és Irodalom (Život i književnost). ${ }^{8}$ Od nje saznajemo da je dan nakon dolaska putovao na Balaton kako bi se okupao, a sljedeći je dan potražio svog izdavača jer je drugo izda-

4 Fejtő, Budapesttől Párizsig: Emlékeim, 132.

5 Fejtő Ferenc, „Megjegyzés Szerdahelyi Istvánnak a Kritika, 1988. decemberi számában megjelent cikkéhez", Kritika, 1989. 3. sz.14.

6 Földes, Anita, Átéltem egy évszázadot, (Budapest: Scolar Kiadó, 2014), 245.

7 Földes. Átéltem egy évszázadot, 245.

8 Széchenyi Ágnes, „Fehérek között egy nagykanizsai - Fejtő Ferenc 1909-2008”, Élet és Irodalom, 2008. június 12. 
nje Sentimentalnog putovanja bilo u pripremi. Neprekidno je davao intervjue. 16. lipnja prisustvovao je pogrebu Imrea Nagya i ostalih mučenika. Idući dan večerao je kod obitelji Ágnes Széchenyi zajedno s Györgyem Litvánom, Miklósem Lackóm, Erzsébet Vezér i Györgyem Konrádom. Tih je dana objedovao i s Rezsőom Nyersem, a na večeru izdavačke kuće Magvető uz njega su bili pozvani sljedeći književnici: Péter Esterházy, Péter Nádas, Miklós Mészöly, György Petri i István Eörsi. Osim s njima, susreo se i sa Sándorom Csoórijem i Dénesem Csengeyem koji su tada bili članovi predsjedništva Mađarskog demokratskog foruma. Ne sjećam se jesu li oni pored brojnih obaveza koje smo imali tih dana uži krug stranke izvijestili i o tom sastanku.

Zanimljivo je kako tek u svojem zadnjem intervjuu (Átéltem egy évszázadot) spominje kako se sastao s Viktorom Orbánom. „...duboki je utisak na mene ostavio mladi Viktor Orbán. On je potražio mene, nakon što je održao svoj veliki govor na Trgu heroja. Zajedno smo nešto pojeli i uistinu se dobro razumjeli. Tada je još bio otvoreniji od Józsefa Antalla. U pojedinim je aspektima mogućim smatrao da se udruži sa strankama Szabad Demokraták Szövetsége (Savez slobodnih demokrata) i Magyar Szocialista Párt (Mađarska socijalistička partija) [bilješka: tada još Magyar Szocialista Munkáspárt (Mađarska socijalistička radnička partija)]. Tog mi je dana rekao: »Striček Feri, moram Vam reći: želim biti premijer Mađarske«". Viktor Orbán mu je to navodno rekao tek 1992. $\mathrm{Na}$ taj je povijesni dan Ferenc Fejtö uvečer sudjelovao i na zajedničkom banketu političkih stranaka i Vijeća za povijesnu pravdu. Sigurno je da na taj banket nisu bili pozvani zastupnici Mađarskog demokratskog foruma. Iz sjećanja Miklósa Vásárhelyija znamo, a i sam dobro pamtim: Vijeće za povijesnu pravdu strogo se ogradilo od toga da na svečanosti ponovnog pokopa Mađarski demokratski forum uopće dobije riječ. Uzalud je Sándor Lezsák pokušavao nagovoriti Miklósa Vásárhelyija da i Sándor Csóori dobije riječ. Oko toga se nikako nisu htjeli složiti. Vijeće za povijesnu pravdu nije moglo zanemariti činjenicu da je jedino Mađarski demokratski forum imao uvježbane redare koji su osiguravali okupljanje, organizacijsku gardu (koja se već dokazala na prosvjedu protiv rušenja mađarskih sela u Rumunjskoj 1988.), tako su se, htjeline htjeli, pomirili sa skupinom redara MDF-a od 1500 osoba. Ujutro oko osam stigao sam na Trg heroja s bečkim Mađarima. Redari budimskog ogranka s trakama Mađarskog demokratskog foruma oko ruku pokazivali su nam put kod Gradskog parka. Mnoštvo stranih političara i novinara vrludalo je Trgom heroja nakon završetka svečane ceremonije, nije bilo kraja razgovorima i intervjuima. Tada se nisam susreo s Ferencom Fejtöm.

Put ga je ponovno doveo u Mađarsku kada je u siječnju 1990. u pratnji predsjednika Mitteranda stigao u Budimpeštu. Već je Károly Grósz pozvao francu-

9 Földes, Átéltem egy évszázadot, 372. 
skog predsjednika u posjet, no tada je kod nas već bila započela predizborna kampanja. Na važnost tog posjeta ukazuje to što je Mitterand u mađarski glavni grad stigao u pratnji sedam ministara. Kasnije se Ferenc Fejtö ovako prisjećao: „Koliku mi je važnost Mitterand iskazivao pokazuje i to što me poveo i na razgovor koji je trebao voditi u četiri oka! ... u Mađarskoj sam mogao sudjelovati u službenim pregovorima."10 Tad je izvijestio i o razgovoru koji je vodio s predsjednikom Mađarskog demokratskog foruma: „Na banketu sam sjedio pored Józsefa Antalla. Razgovarali smo dva sata... Pitao me kako zamišljam promjenu. Odgovorio sam da u teoriji vidim gouvernement du salut public (koalicijsku vladu sastavljenu u svrhu općeg dobra). Antall je izjavio da je za demokraciju potrebna snažna desnica i snažna ljevica, te da se politika formira njihovim nadmetanjem. Takvo shvaćanje može se ostvariti samo odgovorio sam - kada narod ne čeka obnova za koju je potrebno jedinstvo, u tom slučaju ne smije se gubiti vrijeme na borbu za vlast i energija potrebna za obnovu. [...] Antall nije bio pristaša te ideje. Oko toga smo se prepirali cijelu večer, niti sam ja uvjerio njega, niti je on uvjerio mene."11 Ne znam u kojoj je mjeri njegove političke sklonosti odražavalo to što je 1990. - po prisjećanju Ágnes Széchenyi - tražio da na večeru pozovu Rezsőa Nyersa i Gyulu Horna. ${ }^{12}$

Drugi broj časopisa Századvég iz 1990. godine posvećen je raspravi narodnih i urbanih pisaca. Karakteristično je bilo kako je taj broj dobio naslov: prema naslovu studije Jánosa Gyurgyáka: Népiek és urbánusok - egy mítosz vége? (Narodni i urbani pisci - kraj jednog mita?). Mnogo je mađarskih intelektualaca toga vremena sudjelovalo u tom sučeljavanju mišljenja, bilo kao autori izlaganja, bilo kao pozvani da se izjasne po tom pitanju. Još je i danas riječ o vrlo poučnim i dijelom važećim primjedbama, bez obzira na to što među sudionicima jedva nalazimo osobe koje su se ubrajale, kako se obično govorilo, u tzv. narodne pisce. Tijekom sastavljanja broja Mihály Hamburger i Péter Várdy priredili su intervju s Ferencom Fejtöm. Ni tom prilikom nije škrtario na riječima kojima oštro kritizira Gyulu Illyésa i Lászla Németha. O Illyésu piše: „...u jednu ruku je duboki antisemit, a u drugu i humanist i europejac. Ponovo ovako karakterizira Lászla Németha: „Lászla Németha s gledišta mađarske kulture smatram jednom od najštetnijih ličnosti jer je Trianonom već ionako suženo mađarstvo, kojemu je bilo prijeko potrebno da se u manjinskoj situaciji ojača i obogati novim elementima, on još više suzio. Ja sam to već tada smatrao [...] skoro izdajom domovine."13 Te smo retke mogli pročitati u odlučujućim mjesecima demokratskog zaokreta. Te etikete nisu pomogle u međusobnom razumijevanju i nacionalnom jedinstvu.

\footnotetext{
${ }^{10}$ Földes, Átéltem egy évszázadot, 369.

${ }^{11}$ Földes, Átéltem egy évszázadot, 369.

12 Földes, Átéltem egy évszázadot, 370.

${ }^{13}$ Gyurgyák János, „Népiek és urbánusok - egy mítosz vége?”, Századvég, 1990. 2.
} 
I konačno bih, ne kao objašnjenje, već kao dopunu želio postaviti jedno pitanje. To jest, ponoviti pitanje koje je postavio sam sebi i odgovor na njega. Je li Ferenc Fejtö dobro poznavao sam sebe kada je u prisjećanjima pod naslovom A század utasa (Putnik stoljeća) ovako predstavio svoj habitus: „Moja je greška, ako je to greška, što mislim i pišem ne samo hladne glave, toliko hladne koliko je to moguće, već i cijelim svojim bićem."14

Preveli Isabelle Kristović, Ružica Kovač, Dávid Karácsonyi, Ema Sabo, Martin Sukalić

(Rad je preveden u sklopu kolegija Književno prevođenje ak. god. 2018/19. Voditeljica: Kristina Katalinić)

\section{Literatura}

Fejtő, Ferenc. Budapesttől Párizsig: Emlékeim. Budapest: Magvető, 1990.

Fejtő, Ferenc-Serra, Maurizio. A század utasa. Háborúk, forradalmak, Egyesült Európa. Budapest: Holnap Kiadó, 1999.

Földes, Anita. Átéltem egy évszázadot. Budapest: Scolar Kiadó, 2014.

Széchenyi, Ágnes. „Kérdések a Válaszról (Fejtő Ferenccel beszélget Széchenyi Ágnes)", Kritika 26, 12.sz. (1988): 11-16.

Széchenyi, Ágnes. „Fehérek között egy nagykanizsai - Fejtő Ferenc 19092008” Élet és Irodalom, 2008. június 12.

Gyurgyák, János. „Népiek és urbánusok - egy mítosz vége?” Századvég, 1990. 2.

${ }^{14}$ Fejtő Ferenc-Maurizio Serra. A század utasa. Háborúk, forradalmak, Egyesült Európa (Budapest: Holnap Kiadó, 1999), 346. 


\section{Fejtő Ferenc és Magyarország 1988-1989-ben Töredékes emléklapok}

Személyesen 1988. május 26-án ismertem meg Fejtő Ferencet, az Osztrák Televízió Club 2 címú Magyarországról szóló vitaműsorában vettünk részt. Akkor már folytak Párizsban az Emberi Jogok Ligája magyar szekciójában annak a megemlékezésnek az előkészületei, amelyet Nagy Imre és mártírtársai kivégzésének 30. évfordulójára terveztek a Père Lachaise temetőben. Egy évvel később, az újratemetés alkalmából járt ismét újra hazájában. Fejtő Ferenc figyelemmel kísérte, mi történik akkor Magyarországon, a francia szellemi és politikai élet különböző tényezői gyakran fordultak hozzá információért mint térségünk ismerőjéhez. Azt kívánom vázlatosan bemutatni, hogyan látta a magyarországi politikai fordulatot.

Kulcsszavak: 1988-1990, politikai átmenet Magyarországon, a népi-urbánus vita újraélesztése, Illyés Gyula, Németh László 


\section{5 \\ KISS \\ Gy. Csaba}

\section{Budapest}

\section{Fejtő Ferenc és Magyarország 1988-1990-ben Töredékes emléklapok}

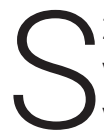

zemélyes mozzanattal szeretném kezdeni. 1988. május 26-án este hivatalosak voltunk a bécsi televízió Club 2 című Paul Lendvai/Lendvai Pál vezette vitaműsorába, Andics Jenővel, a pártközpont osztályvezetőjével és az akkor Nyugat-Németországban élő Dalos Györggyel együtt. Kádár menesztése után néhány nappal. Fejtő Ferenc neve nem volt ismeretlen előttem. Jól emlékszem, 1976-ban varsói ösztöndíjasként olvashattam könyveit franciául. A magyar forradalomról és a népi demokráciák történetéről. A varsói Nemzetközi Tanulmányok Intézetéből minden további nélkül ki lehetett kölcsönözni ezeket a munkákat. Az Érzelmes utazást pedig még az 80-as évek elején találtam meg itthon egy antikváriumban. Erre kértem tőle a műsor előtt Bécsben dedikációt. A következő sorokat írta bele: „Kiss György Csabának ezt a könyvet rokonszenvvel személye és mozgalma iránt. Bécs, 1988 májusában." Hogy félreértés ne essék, ez a mozgalom a Magyar Demokrata Fórum volt. Másnap reggelinél a szállodában azt kérdezte tőlem, mit csinálok délelőtt Bécsben. Néhány kisebb vásárlást kell intéznem, mire ő, hogy elkísérne. Így kérdezgetett azután a Kärtnerstrassén sétálva a „mozgalmamról”. Mint aki mindenre kíváncsi. Ekkor már túl voltunk a Nyilvánosság Klubbal együtt rendezett május 15-i Jurta Színházban tartott fórumon, ahol a tömegtájékoztatás volt napirenden. A szervező munka dandárját éltük azokban a napokban, bizonyára beszéltem neki a romániai magyarság helyzetéről készített, nem- 
zetközi nyilvánosságnak szánt „jelentésünkről”. Folyton kérdezett, arról nem tudtam képet alkotni, hogy miképpen látja ő a mi esélyeinket.

Június 16-án azután hallottunk Nagy Imréék jelképes párizsi temetéséről a Père Lachaise temetőben. Az ünnepélyes szertartásnak fő szervezője Fejtő Ferenc volt, mint a franciaországi Emberi Jogok Magyar Ligájának elnöke. Azt csak később tudtam meg, hogy az év nyarán fejezte be nagy közép-európai művét, a Rekviem egy hajdanvolt birodalomért című történelmi esszét.

Mivel nem vagyok munkásságának kutatója, előadásomban csupán néhány mozaikot szeretnék kronologikus rendben fölidézni arról, hogy miként reagált Fejtő Ferenc a magyarországi változásokra a sorsdöntő esztendőkben. Hozzátenném, sokszor elmondtam, de szüntelen aktuálisnak érzem, hogy a kort „rendszerváltásnak” nevezni sajátos hungaricum. Más nyelvekben a kommunizmus bukásáról, a szovjet típusú totalitarizmus végéről, fordulatról, átmenetről beszélnek. A magyar terminus homályban hagyja, hogy rendszer és rendszer között minőségi volt a különbség, nem beszélve arról, hogy a mi esetünkben a változás a megszálló csapatok távozásával járt. Egy olyan különös modernizációs kísérletnek lett ezzel vége, amelyet egy, a civilizáció tekintetében tőlünk elmaradott nagyhatalom kényszerített ránk. Nyilvánvaló egyébként, nálunk a posztkommunista törekvések leplezésére szolgált a rendszerváltás kifejezés.

Kérdés számomra, hogy mit gondolt Fejtő Ferenc saját lehetséges szerepéről az átmenet során. Azt tudjuk, hogy a francia politikai és szellemi élet az egyik első számú közép-európai szakértőnek tartotta. Életpályájáról és mentalitásáról némi képet alkotván úgy gondolom, valaminő küldetéstudatot érzett ebben az ügyben. Nehéz volna arról számot adni, mekkora volt - ha volt - szerepe a magyar átalakulásban. Valóságos hatását nehéz lemérni, hiszen fölgyorsultak az események; a nemzetközi politika meghatározó erői és a dinamizálódó hazai mozgalmak a megfigyelőket és a szereplőket is meglepték.

Mindenképpen jelentős hozzászólás volt a mi ügyeinkhez, ha nem ilyen szándékkal készült is, a Széchenyi Ágnes által készített nagy interjú a Kritika 1988. decemberi számában. Úgy tudni, hogy egy évvel korábban vették föl az anyagát. Ez a szöveg ugyan elsősorban visszaemlékezés, de a népi-urbánus vita fölidézésével akaratlan is volt szellemi-politikai üzenete, hiszen a formálódó ellenzéki csoportok két jelentős mozgalmának elkülönítésére szintén használták a külföldi elemzők ezt a megkülönböztetést. 1988. január 30-án a Jurta Színházban a parlamentarizmusról tartott vitában ugyan egymás után szólalt föl Bíró Zoltán és Kis János, Konrád György, Csurka István és Szabad György, május 1-étől már kirajzolódott bizonyos elválasztó vonal, akkor alakult meg szervezetként a Szabad Kezdeményezések Hálózata. A Magyar Demokrata Fórum ez időben csupán a szervezők kilenc főre bővült csoportját jelentette. Nos, Fejtő Ferenc interjúja bizonyos fokig aktualizálta azt a szembenál- 
lást, amelyet a kommunista hatalom is hosszú időn át előszeretettel használt manipulációra. Érdemes megfigyelni a titkosszolgálatok nyelvét, jól követhető a jelentéseikben a kétosztatú séma: polgári radikális ellenzék versus nacionalista ellenzék és hasonlók. Fejtő Ferenc pedig mintha a 30-as évek vitáit folytatná 1988-ban: „Meg kell jegyeznem - írja -, hogy a »népies irodalom《 - úgy mint specifikus magyar jelenség - rokonságban áll az úgynevezett narodnyikokkal és a populistákkal, egy bizonyos francia irányzattal - »vissza a földhöz«, amely a szélső nacionalista Barrès nevéhez füződik."1 A népi írók folyóiratáról, a Válaszról kerek perec azt állítja, a demokrácia nem érdekelte ezt a lapot. Szerinte Illyés Gyula is valahogy zárójelbe tette munkásságában a demokráciát. Különösen éles Fejtőnél Németh László megítélése: „Meg kell mondanom, hogy Németh Lászlót tartom talán a legkártevőbb elemnek ebben az egész garnitúrában. Talán épp azért, mert másrészt igen nagyra lehet becsülni mint tehetséges regényírót és mint rendkívül nagy műveltségű, univerzális tájékozódású esszéírót. De az ő, hogy is mondjam, éppen a népiségre, mélymagyarságra, a kultúra zsidótlanítására vonatkozó teóriái, úgy látom, évszázadra szóló zavart okoztak a magyar értelmiség szellemében.[...] Németh László átvett egy olyan doktrínát, amelyik - mindabból, amit hallok, ezt következtetem - ma is nyilvánvalóan tovább él, sőt talán többségben van az értelmiség, a középosztály körében, de ami tulajdonképpen a magyarságnak európai nívóra való emelkedését huzamosan gátolta és valószínűleg még gátolni is fogja." ${ }^{2}$ Azt hiszem, nehéz volna cáfolni, hogy ezek a szavak az akkori kortársaknak küldött üzenetnek is vehetők. Az sem közömbös természetesen, melyik orgánumból szólt. A hatalomnak elkötelezett, akkor már reformkommunista kilengéseket is magának megengedő folyóiratban.

Hasonló tónusúak azok a megjegyzései - szintén a 80-as évek második feléből - melyeket a magyarul 1990-ben Budapesttől Párizsig: Emlékeim címmel megjelent visszaemlékezéseiben tett. Most is következetesen a náci völkischre rímelő népies kifejezést használja. „A népiesség ott a legerősebb, ahol a modernizmus egy különösen hierarchikus és hagyományokhoz mereven ragaszkodó társadalomba tör be. Ez volt a helyzet Magyarországon. Ilyenkor a népiesség reakció; mégpedig lázadó reakció a tőkés iparosítás folyamata ellen, amelyet Marx és Engels oly ragyogóan elemzett a Kommunista Kiáltványban, 1847-48-ban.” ${ }^{3}$ Vagy a következőkben: „Tény, ellenállást fejt ki ma is a kommunista rendszerrel szemben. Vajon ez a befolyás nacionalista retorikájuknak tulajdonítható, amelyben mindig vannak antiszemita felhangok? Vagy talán annak, hogy látszólag van megoldásuk a Kelet és Nyugat közé szorult

1 Széchenyi Ágnes, „Kérdések a Válaszról (interjú Fejtő Ferenccel)”, Kritika 26, 12. sz. (1988): 11-16.

2 Széchenyi Ágnes, „Kérdések a Válaszról”, Kritika 26, 12.sz. (1988): 11-16.

3 Fejtő Ferenc, Budapesttől Párizsig: Emlékeim, (Budapest: Magvető Kiadó, 1990), 124. 
magyar nép dilemmájára."4 Következetesen a "népies” kifejezést használja, aminek önmagában is volt némi megbélyegző íze. A Kommunista Kiáltványra történő hivatkozás pedig akkor enyhén szólva groteszknek hangzott.

A Kritikában az 1989 elején, az interjú kapcsán polémia alakult ki, Szerdahelyi főszerkesztő (a kommunista irodalmi establishment fontos tagja) néhány bíráló megjegyzést füzött Fejtő múltidézéséhez. Ezt a megbírált határozott szavakkal utasíthatta vissza a cenzúra akkor már enyhültebb viszonyai mellett: „Fenntartom, hogy Németh László, Lukács György mellett, a legkártevőbb eleme volt a magyar szellemiségnek. [...] Például ami Németh Lászlót illeti, fönntartom, hogy a Kisebbségben és A minőség forradalma című múveivel, hogy csak e kettőt említsem, a mai antiszemitizmusban is kétségkívül neki van a legdöntőbb szerepe..." ${ }^{\prime \prime}$

Nem tudni, pontosan mikor jutott Fejtő arra a belátásra, hogy a kommunista rendszert bukásra ítélte a történelem. A Földes Anita által készített interjúkötetben fölidézi, hogy 1989 elején részt vett egy olaszországi történészkonferencián, ahol a nyugati szemléletre jellemzően arról vitatkoztak, megreformálható-e a kommunizmus. Hősünk így emlékezett: „....még mindig szinte egyetlen voltam, az egész nemzetközi társaságban, aki azt képviselte, hogy kizárólag decentralizációval és a demokratikus intézmények bevezetésével lehet erre bármi esély." Emlékezetem szerint 1988-ben és 1989 első felében a nyugati politikusok, diplomaták és újságírók többsége az átalakulás „levezénylőit”, békés jellegének biztosítóit elsősorban az ún. reformkommunistákban látták.

Fejtő Ferenc jó fél évszázad után első alkalommal 1989. június 13-án érkezett vissza Magyarországra. Így emlékezett később erre vissza. „Nagy Imre lányával jóban voltunk, az ő hívó szavának boldogan tettem eleget. Visszatérésem napján Kolozsvári Grandpierre Emil és Széchenyi Ágnes irodalomtörténész jöttek elém a reptérre, azután Göncz Árpáddal ebédeltem. Őt az Írószövetség elnökeként ismertem meg 88-ban, amikor Párizsban járt, a népi írók egyik szellemi és politikai vezetőjével együtt. Akkor még mély egyetértés volt közöttük. Csoóri nagy demokrata volt, Göncz pedig az is maradt..."7 Programjának szervezője, Széchenyi Ágnes idézte vissza itt töltött hat napját 2008-ban az Élet és Irodalomban. ${ }^{8}$ Megtudjuk ebből, hogy érkezése másnapján a Balatonhoz utazott, ahol fürdeni akart, másnap pedig kiadóját kereste föl, mivel készült az Érzelmes utazás új kiadása. Szünet nélkül adta az interjúkat. Június 16-án részt vett Nagy Imre és mártírtársainak temetésén. Másnap Széche-

4 Fejtő, Budapesttől Párizsig: Emlékeim, 132.

5 Fejtő Ferenc, „Megjegyzés Szerdahelyi Istvánnak a Kritika, 1988. decemberi számában megjelent cikkéhez", Kritika 7, 3. sz. (1983): 14.

6 Földes Anita. Átéltem egy évszázadot (Budapest: Scolar Kiadó, 2014), 245.

7 Földes, Átéltem egy évszázadot, 245.

8 Széchenyi Ágnes, „Fehérek között egy nagykanizsai i Fejtő Ferenc 1909-2008”, Élet és Irodalom, 2008. június 13. 
nyi Ágneséknél együtt vacsorázott Litván Györggyel, Lackó Miklóssal, Vezér Erzsébettel és Konrád Györggyel. E napokban Nyers Rezsővel is ebédelt, a Magvető Kiadó vacsorájára pedig vele együtt a következő írók voltak oda hivatalosak: Esterházy Péter, Nádas Péter, Mészöly Miklós, Petri György és Eörsi István. Találkozott rajtuk kívül Csoóri Sándorral és Csengey Dénessel, akik akkor a Magyar Demokrata Fórum elnökségének a tagjai voltak. Nem emlékszem arra, hogy azoknak a napoknak sűrű teendői között beszámoltak-e ők szűkebb körben erről a találkozásról.

Érdekes, hogy csak utolsó interjújában (Átéltem egy évszázadot) említi találkozását Orbán Viktorral. „[...] mély benyomást tett rám a fiatal Orbán Viktor. Ő keresett meg, miután megtartotta nagy beszédét a Hősök terén. Együtt uzsonnáztunk, és igen jól megértettük egymást. Akkor még nyitottabb volt, mint Antall József. Bizonyos kérdésekben elképzelhetőnek tartotta, hogy közösen lépjen fel az SzDSz-szel és az MSzP-vel [megjegyzés: akkor még MSzMP]. Aznap azt mondta nekem: »Feri bácsi, meg kell mondanom magának: én Magyarország miniszterelnöke akarok lenni«."9 Állítólag ezt csak 1992-ben mondta neki Orbán Viktor. Hozzátartozik még a történelmi naphoz, hogy Fejtő Ferenc részt vett este a Történelmi Igazságtétel Bizottság és a politikai pártok közös bankettjén. Annyi bizonyos, hogy a Magyar Demokrata Fórum képviselői ide nem voltak hivatalosak. Vásárhelyi Miklós emlékezéseiből tudjuk, magam is úgy emlékezem: a Történelmi Igazságtétel Bizottság mereven elzárkózott attól, hogy az ünnepélyes újratemetésen a Magyar Demokrata Fórum bármilyen formában szót kapjon. Hiába próbálta Lezsák Sándor meggyőzni Vásárhelyi Miklóst, hogy Csoóri Sándor is kapjon szót. Ebbe semmiképpen nem akartak beleegyezni. A Történelmi Igazságtétel Bizottsága azonban nem tudott eltekinteni attól, hogy csupán ennek a szervezetnek volt kipróbált rendezőgárdája (az 1988-as romániai falurombolás elleni tüntetésén már bizonyított), így kénytelen-kelletlen rászorultak a mintegy 1500 fős csoportra. Reggel kilenc óra tájban bécsi magyarokkal érkeztem a Hősök teréhez. Budai szervezeteink MDF-s karszalaggal dekorált szervezői irányítottak útba bennünket a Városligetnél. Rengeteg külhoni politikus, újságíró lófrált az ünnepi szertartás befejezése után a Hősök terén, vége-hossza nem volt a beszélgetéseknek, interjúknak. Fejtő Ferenccel ekkor nem találkoztam.

Akkor vezetett ismét Magyarországra útja, amikor Mitterand elnök kíséretében érkezett 1990 januárjában Budapestre. A francia elnököt még Grósz Károly hívta meg látogatásra, de ekkor már megkezdődött nálunk a választási kampány. A látogatás jelentőségét mutatja, hogy Mitterand-t hét miniszter is elkísérte a magyar fővárosba. Fejtő Ferenc később így em-

9 Földes, Átéltem egy évszázadot, 372. 
lékezett: „Aztán komoly gesztust gyakorolt Mitterand felém azzal, hogy még a négyszemközti beszélgetésre is bevitt magával! [...] én Magyarországon részt vehettem a hivatalos tárgyalásokon."10 Itt számolt be arról a beszélgetésről is, melyet az MDF elnökével folytatott: „Antall József mellett ültem a banketten. Két óra hosszat beszélgettünk... Kérdezte tőlem, hogyan képzelem el a változást? Azt feleltem, elméleti szempontból látnék egy gouvernement du salut public-öt (egy a közjó érdekében életre hívott koaliciós kormányt). Antall azt mondta, hogy a demokráciához erős jobboldal és erős baloldal kell, és ezek versengéséből alakul a politika. Ezt a felfogást csak akkor lehet érvényesíteni - feleltem -, amikor a nemzet nem újjáépítés előtt áll, amelyhez egység kell, akkor nem vesztegethetnek el a hatalomért való küzdelemben annyi időt és az újjáépítéshez szükséges energiát. [...] Antall nem volt híve ennek a koncepciónak. Erről vitatkoztunk egész este, én nem győztem meg őt, ő nem győzött meg engem."11 Nem tudom, mennyiben tükrözte politikai preferenciáit, hogy 1990-ben - Széchenyi Ágnes visszaemlékezése szerint - arra kérte, hogy hívják meg vacsorára Nyers Rezsőt és Horn Gyulát. ${ }^{12}$

A Századvég című folyóirat 1990. 2. számát a népi-urbánus vitának szentelték. Jellemző volt a címadás, Gyurgyák János tanulmányának a címéből: Népiek és urbánusok - egy mítosz vége? A korabeli magyar szellemi élet széles spektruma volt jelen ebben a vállalkozásban, mint tanulmányok szerzője, illetve mint a körkérdésre választ adók csoportja. Mindmáig nagyon tanulságos és részben érvényes hozzászólásokról van szó, ha a résztvevők között nemigen találunk is a közbeszéd szerint az ún. népiek közé számított személyeket. Hamburger Mihály és Várdy Péter készített a folyóirat összeállitásában interjút Fejtő Ferenccel. Ez alkalommal sem fukarkodik az Illyés Gyulát és Németh Lászlót keményen bíráló szavakkal. Illyésről írja: „....egyrészt mélységesen antiszemita, másrészt pedig humanista és európéer is." Így jellemzi ismét Németh Lászlót: „Azért tartom Németh Lászlót a magyar kultúra szempontjából a legkártékonyabb egyéniségek egyikének, mert a magyarságot, amelynek nagy szüksége volt arra, hogy kisebbségi helyzetében megerősödjék és gazdagodjék újabb elemekkel, ő akkor tovább szúkítette ezt a már Trianon által úgyis leszúkített magyarságot. Ezt én már akkor úgy tekintettem [...] majd mint egy hazaárulást." ${ }^{13}$ Olvashattuk ezeket a sorokat a demokratikus fordulat sorsdöntő hónapjaiban. Nem a kölcsönös megértést, a nemzeti egységet segítették ezek a címkék.

\footnotetext{
${ }^{10}$ Földes, Átéltem egy évszázadot,369.

${ }^{11}$ Földes, Átéltem egy évszázadot, 369.

12 Földes, Átéltem egy évszázadot, 370.

13 „Népiek és urbánusok - egy mítosz vége?", Hamburger Mihály és Várdy Péter beszélgetése Fejtő Ferenccel, Századvég, 1990. 2.
} 
Befejezésül pedig: nem magyarázatul, hanem kiegészítésként. Egy kérdést szeretnék csupán föltenni. Mégpedig megismételni a saját magának föltett kérdést és hozzá a választ. Jól ismerte-e magát Fejtő Ferenc, amikor saját habitusát így mutatta be A század utasa című visszaemlékezésében: „Megvan az a hibám, ha ez hiba, hogy nemcsak hideg fejjel gondolkodom és írok, annyira hideggel, amennyire csak lehet, hanem a zsigereimmel is." ${ }^{14}$ ?

\section{Irodalom}

Fejtő, Ferenc. Budapesttől Párizsig: Emlékeim. Budapest: Magvető Kiadó,1990. Fejtő, Ferenc-Serra, Maurizio. A század utasa: Háborúk, forradalmak, Egyesült Európa. Budapest: Holnap Kiadó, 1999.

Földes Anita. Átéltem egy évszázadot. Budapest: Scolar Kiadó, 2014.

Széchenyi Ágnes. „Kérdések a Válaszról (interjú Fejtő Ferenccel)”. Kritika, 26, 12. sz. (1988): 11-16.

Széchenyi Ágnes. „Fehérek között egy nagykanizsai - Fejtő Ferenc 19092008". Élet és Irodalom, 2008. jún. 13.

„Népiek és urbánusok - egy mítosz vége? Hamburger Mihály és Várdy Péter beszélgetése Fejtő Ferenccel”. Századvég, 1990. 2.

${ }^{14}$ Fejtő Ferenc-Maurizio Serra, A század utasa. Háborúk, forradalmak, Egyesült Európa (Budapest: Holnap Kiadó, 1999), 346. 


\section{Ferenc Fejtö i Mađarska između 1988. i 1990. Nedovršeni zapisi}

Osobno sam 26. svibnja 1988. upoznao Ferenca Fejtöa kada smo obojica bili sudionici talk showa Austrijske televizije pod nazivom Club 2 koja se bavila Mađarskom. Tada su već bile u tijeku pripreme komemoracije na pariškom groblju Père Lachaise povodom 30. godišnjice smaknuća mađarskog predsjednika vlade Imrea Nagya i njegovih suradnika u organizaciji mađarske sekcije Lige za ljudska prava. Godinu dana kasnije, u prigodi ponovnog pogreba Imrea Nagya Fejtő je opet posjetio svoju domovinu. Pratio je tadašnje mađarske događaje, a različiti sudionici francuskog duhovnog i političkog života često su mu se kao dobrom poznavatelju naših prostora i prilika obraćali za informacije. U svome izlaganju u većim crtama želim predstaviti kako je Fejtö vidio politički preokret u Mađarskoj.

Ključne riječi: godine 1988-1990, politički prijelaz u Mađarskoj, oživljavanje rasprave o narodnim i urbanim piscima, Gyula Illyés, László Németh 